\title{
ROZPOZNANIE SPRAWY PRZEZ SĄD ADMINISTRACYJNY BEZ NIEUZASADNIONEJ ZWKOKI*
}

\section{UWAGI WPROWADZAJĄCE}

Kiedy na początku $2004 \mathrm{r}$. wchodziły w życie ustawy reformujące sądownictwo administracyjne w Polsce, w doktrynie formułowane były poglądy zarówno prognozujace przyspieszenie rozpoznawania spraw przez te sądy ${ }^{1}$, jak i upatrujące szybkość postępowania sądowoadministracyjnego „w czarnych barwach"2. Po upływie prawie trzynastu lat od tamtego czasu warto powrócić do sformułowanych dawniej nadziei oraz obaw łączących się z realizacją wyrażonego w art. 236 ust. 2 Konstytucji $\mathrm{RP}^{3}$ wymagania ustanowienia dwuinstancyjnego sądownictwa administracyjnego. Trzeba $\mathrm{w}$ tym miejscu zadać sobie pytanie, czy obecny model sądowej kontroli administracji publicznej w Polsce, o którym stanowia przepisy p.p.s.a. ${ }^{4}$, realizuje konstytucyjny wymóg rozpoznania sprawy przez sąd bez nieuzasadnionej zwłoki, a także jakie rozwiązania legislacyjne sprzyjają szybkości postępowania sądowoadministracyjnego, a które spośród nich tamuja jego bieg.

Sprawność oraz szybkość postępowań sądowych jest elementem prawa do sądu, o którym stanowią zarówno art. 45 ust. 1 Konstytucji RP, jak i prawo międzynarodowe, w tym art. 6 Konwencji ${ }^{5}$ oraz art. 47 Karty praw podstawowych $\mathrm{UE}^{6}$. O doniosłości tego aspektu prawa do sądu świadczy orzecznictwo Europejskiego Trybunału Praw Człowieka (ETPC), które wywarło istotny wpływ na uchwalenie przez polskiego prawodawcę specjalnej ustawy mającej na celu ochronę praw jednostki przed przewlekłym prowadzeniem postępowa-

\footnotetext{
*Artykuł stanowi poszerzoną wersję wykładu wygłoszonego podczas uroczystości wręczenia dyplomów doktorskich i habilitacyjnych na Wydziale Prawa i Administracji Uniwersytetu im. Adama Mickiewicza w Poznaniu 22 października 2016 r.

${ }^{1}$ R. Hauser, U progu reformy sqdownictwa administracyjnego, „Państwo i Prawo” 2002, z. 11, s. 28 i n.

${ }^{2}$ Sformułowanie to zostało użyte przez T. Wosia na końcu artykułu Dwuinstancyjne sqdownictwo administracyjne a konstytucyjne prawo do rozpatrzenia sprawy „bez nieuzasadnionej zwtoki”, „Państwo i Prawo” 2003, z. 8, s. 35.

${ }^{3}$ Konstytucja RP z 2 kwietnia 1997 r., Dz.U. 1997, Nr 78, poz. 483 ze zm. (dalej jako: Konstytucja RP).

${ }^{4}$ Ustawa z 30 sierpnia 2002 r. - Prawo o postępowaniu przed sądami administracyjnymi, t.jedn.: Dz.U. 2016, poz. 718 ze zm. (dalej jako p.p.s.a.).

${ }^{5}$ Konwencja o ochronie praw człowieka i podstawowych wolności z 4 listopada 1950 r., Dz. U. 1993, Nr 61, poz. 284 ze zm. (dalej jako: Konwencja).

${ }^{6}$ Karta praw podstawowych Unii Europejskiej, Dz. Urz. UE C 2007.303.1 (dalej jako: Karta).
} 
nia ${ }^{7}$. W art. 2 ust. 2 tej ustawy, w ślad za orzecznictwem ETPC, sformułowane zostały wyznaczniki pozwalające na ustalenie, czy w konkretnym postępowaniu przewlekłość ta rzeczywiście wystapiła. Należą do nich charakter sprawy, stopień jej faktycznej i prawnej zawiłości, znaczenie sprawy dla stron, a przede wszystkim tej, która wniosła skargę, oraz zachowanie się stron, a w szczególności tej, która zarzuciła przewlekłość postępowania.

Chociaż niemożliwe jest wyznaczenie jednego terminu, po którego upływie postępowanie sądowe staje się przewlekłe ${ }^{8}$, to prawo do rozpoznania sprawy przez sąd bez nieuzasadnionej zwłoki nie może być współcześnie rozumiane jedynie jako postulat adresowany do sądu, który powinien w każdej sprawie działać zarazem wnikliwie oraz szybko. Analizowane prawo powinno być raczej pojmowane w kategoriach publicznego prawa podmiotowego jednostki, na równi z prawem do sprawiedliwego i jawnego rozpoznania sprawy. Adresowane jest ono nie tylko do każdego sądu, lecz także do ustawodawcy - powinien on stworzyć sądom takie warunki ustrojowe oraz procesowe, które umożliwią im rozpoznawanie spraw bez nieuzasadnionej zwłoki.

Powracając myślą do sądownictwa administracyjnego, w okresie ostatnich dwunastu lat ramy procesowe jego działania zostały jeden raz poddane kompleksowej nowelizacji ${ }^{9}$. W'śród jej motywów wskazano na potrzebę zwiększenia szybkości oraz efektywności ochrony prawnej udzielanej w postępowaniu sadowoadministracyjnym ${ }^{10}$. Pytanie, jakie $\mathrm{w}$ tym momencie warto postawić, dotyczy tego, czy wprowadzone zmiany w p.p.s.a. doprowadziły do osiagnięcia będacych u ich podstaw założeń, a także czy obrany kierunek zmian procesowych powinien ulec dalszemu pogłębieniu.

Sformułowane pytanie ma tym bardziej fundamentalny charakter, skoro szybkość wymierzania sprawiedliwości przez sądy administracyjne odgrywa niebagatelne znaczenie z punktu widzenia zarówno ochrony praw jednostki, jak i obiektywnego porządku prawnego. Niejednokrotnie opóźnienia w tym względzie mogą bowiem doprowadzić do powstania nieodwracalnych skutków zarówno prawnych, jak i faktycznych, kiedy to ocena legalności zaskarżonego przejawu działania albo zaniechania administracji publicznej traci swój podstawowy i pierwotny sens ${ }^{11}$.

7 Ustawa z 17 czerwca 2004 r. o skardze na naruszenie prawa strony do rozpoznania sprawy w postępowaniu przygotowawczym prowadzonym lub nadzorowanym przez prokuratora i postępowaniu sądowym bez nieuzasadnionej zwłoki, t.jedn.: Dz.U. 2016, poz. 1259 ze zm. Zob. wyrok ETPCz z 26 października 2000 r., Kudła v. Polska, nr 30201/96. Ostatnio zob. także wyrok ETPC z 7 lipca 2015 r., Rutkowski i inni v. Polska, nr 72287/10, Lex nr 1749574.

${ }^{8} \mathrm{~W}$ sądowych regulacjach procesowych nie wprowadzono rozwiązania zbliżonego swoją treścią do art. 35 § 3 ustawy z 14 czerwca 1960 r. - Kodeks postępowania administracyjnego (t.jedn.: Dz. U. 2016, poz. 23 ze zm.), w którym wprowadzony został dokładny termin, po którego upływie organ staje się bezczynny.

${ }^{9}$ Nastapiła ona moca ustawy z 9 kwietnia 2015 r. o zmianie ustawy - Prawo o postępowaniu przed sądami administracyjnymi, Dz. U. 2015, poz. 658, która weszła w życie 15 sierpnia 2015 r. (dalej jako: ustawa z 9 kwietnia 2015 r.).

${ }_{10}$ Zob. uzasadnienie projektu ustawy z 9 kwietnia 2015 r. http://www.sejm.gov.pl/Sejm7.nsf/ druk.xsp?nr=1633 [dostęp: 29.11.2016].

11 Zgodnie z art. $61 \S 1$ p.p.s.a., wniesienie skargi nie wstrzymuje wykonania aktu lub czynności. Wyjątki od tej zasady określone w art. $61 \S 2$ i 3 p.p.s.a. nie mogą podlegać wykładni roz- 


\section{ROZPOZNANIE SKARGI PRZEZ SĄD ADMINISTRACYJNY W UJĘCIU LICZBOWYM}

Zanim analizie poddane zostana proceduralne uwarunkowania rozpoznania sprawy przez sąd administracyjny pod względem czasowym, warto poświęcić uwagę kwestiom statystycznym. Lektura corocznych sprawozdań z działalności sądów administracyjnych ukazuje bowiem, jak w praktyce sądy administracyjne realizują konstytucyjny wymóg rozpoznawania spraw bez nieuzasadnionej zwłoki.

$\mathrm{Z}$ dniem 1 stycznia 2004 r., tzn. w chwili wejścia w życie ustaw reformujacych sądownictwo administracyjne, wojewódzkie sądy administracyjne przejęły z NSA i jego ośrodków zamiejscowych 92526 spraw. W 2004 r. do sądów I instancji wpłynęło 58815 spraw. Rozpoznanych w tym roku zostało 84459 spraw $^{12}$. W tym samym roku do NSA wpłynęło 6167 skarg kasacyjnych. Rozpatrzona została niespełna połowa z nich w liczbie $2918^{13}$. Oznacza to, że pozostałe skargi kasacyjne rozpatrzone zostały w kolejnych latach.

W 2005 r. do wojewódzkich sądów administracyjnych wpłynęło 62909 skarg, co z pozostałymi 68254 skargami z poprzednich lat dało łączną liczbę 131163 skarg do załatwienia. W tym roku załatwiono ogółem 87383 skarg, co stanowiło $66,6 \% \mathrm{w}$ stosunku do liczby skarg do załatwienia, a na okres następny pozostało do załatwienia 43780 skarg. W porównaniu z 2004 r. liczba zaległych skarg zmniejszyła się o $24,6 \%$, a liczba skarg pozostałych do załatwienia $\mathrm{w}$ kolejnym roku zmalała o $34,7 \%^{14}$. Wzrost dynamiki załatwionych spraw $\mathrm{w}$ stosunku do roku poprzedniego przyczynił się do zmniejszenia czasu oczekiwania na ich rozpatrzenie. Pozytywna tendencja w tym względzie nie objęła swoim zasięgiem NSA, do którego w 2005 r. wpłynęło 9549 skarg kasacyjnych, o 35,5\% więcej aniżeli w 2004 r. W tym roku NSA załatwił 6535 skarg, co stanowiło 51\% ogólnej liczby spraw. Na okres następny pozostały do rozpatrzenia 6263 skargi kasacyjne, co stanowiło 48,9\% ich ogółu ${ }^{15}$.

W 2014 r. do wojewódzkich sądów administracyjnych wpłynęły 84162 skargi, co dało wzrost o 3,1\% w stosunku do roku 2013. Mając na uwadze sprawy z poprzedniego okresu, łącznie sądy I instancji miały do rozpatrzenia 112231 spraw, o 8465 więcej aniżeli w 2013 r. ${ }^{16}$ Z kolei w 2014 r. do NSA wpłynęło 17787 skarg kasacyjnych. Wraz ze sprawami pozostałymi z poprzedniego okresu NSA miał do rozpatrzenia łącznie 37058 skarg kasacyjnych, o 13,11\%

\footnotetext{
szerzającej. Z tych względów w orzecznictwie sądowym przyjęto, że wierzyciel nie ma obowiązku wstrzymania się z egzekucją obowiązku wynikającego z ostatecznej decyzji, przez czas, w jakim podatnik zachowuje prawo do wniesienia skargi do sądu administracyjnego. Zob. wyrok NSA z 14 lipca 2016 r., II FSK 1637/14, CBOSA.

${ }^{12}$ Informacja o dziatalności sqdów administracyjnych w 2004 r., Warszawa 2005, s. 10.

${ }^{13}$ Ibidem, s. 143.

${ }^{14}$ Informacja o działalności sqdów administracyjnych w 2005 r., Warszawa 2006, s. 10.

${ }^{15}$ Ibidem, s. 26.

${ }^{16}$ Informacja o działalności sqdów administracyjnych w 2014 r., Warszawa 2015, s. 15.
} 
więcej aniżeli w 2013 i o 31,13\% więcej niż w 2012 r. W 2015 r. NSA załatwił 14994 skargi kasacyjne, co stanowiło 40,46\% ogółu do rozpoznania ${ }^{17}$.

W 2015 r. do wojewódzkich sądów administracyjnych wpłynęło 83529 skarg. W porównaniu z rokiem poprzednim wpływ zmniejszył się o 633 sprawy. Mając jednak na uwadze sprawy zaległe z 2014 r., sądy I instancji miały do rozpatrzenia 114520 spraw, tj. o $2289(2,04 \%)$ skarg więcej niż w 2014 r. Na okres następny pozostało do rozpatrzenia łącznie 33167 skarg, czyli 2176 więcej niż w 2014 r. ${ }^{18} \mathrm{~W} 2015$ r. do NSA wpłynęły 18634 skargi kasacyjne. Mając na uwadze sprawy z poprzedniego okresu, ogółem NSA miał do rozpatrzenia 40841 skarg kasacyjnych. Wzrost wpływu w porównaniu z minionym okresem wyniósł 8,94\%. W 2015 r. NSA załatwił 50,97\% ogółu spraw w terminie do 12 miesięcy, a w terminie do 24 miesięcy - 90,08\% ${ }^{19}$. W zakresie terminowości załatwiania spraw sytuacja NSA jest porównywalna z czasem procesowania przed sądami administracyjnymi innych państw europejskich. Przykładowo w Hiszpanii okres ten wynosi powyżej 20 miesięcy, w Austrii - około 20 miesięcy, w Szwecji - od 10 do 12 miesięcy, a na Słowacji - 12 miesięcy ${ }^{20}$.

Analiza corocznych sprawozdań z działalności sądów administracyjnych prowadzi do dwóch podstawowych spostrzeżen, a mianowicie systematycznie rosnącej liczby oczekujących na rozpatrzenie skarg i skarg kasacyjnych, co powoduje stopniowe wydłużanie czasu oczekiwania na rozpoznanie sprawy przede wszystkim przed NSA. Zwiększającemu się wpływowi skarg do sądów administracyjnych nie towarzyszy adekwatne powiększanie liczby etatów sędziowskich. Przykładowo, o ile w 2005 r. NSA załatwił 6535 skarg kasacyjnych przy stanie kadry wynoszacym 74 sędziów ${ }^{21}$, o tyle w 2015 r. NSA w składzie osobowym 110 sędziów załatwił 18634 skargi kasacyjne ${ }^{22}$.

Zwiększenie liczby stanowisk sędziowskich nie powinno być podstawowym sposobem przeciwdziałania przewlekłości postępowania sądowego. Niewystarczający zasięg podejmowanych działań o charakterze organizacyjnym skłania do zastanowienia się nad poszukiwaniem innego rodzaju rozwiązań, które przyspieszyłyby rozpoznanie przez sądy administracyjne wnoszonych środków prawnych. Jednym z obszarów, na których problem ten może zostać rozwiązany, pozostaje regulacja p.p.s.a.

\section{PRZYCZYNY PROCESOWE PRZEDŁUŻAJĄCEGO SIĘ CZASU TRWANIA POSTĘPOWANIA SĄDOWOADMINISTRACYJNEGO}

U podstaw zarysowanego powyżej stanu rzeczy związanego z wydłużajacym się czasem rozpatrzenia szczególnie skarg kasacyjnych przed NSA znajdują się wielorakie przyczyny zarówno natury prawnej, jak i pozaprawnej.

17 Ibidem, s. 21.

18 Informacja o działalności sąów administracyjnych w 2015 r., Warszawa 2016, s. 17.

19 Ibidem, s. 22-23.

${ }^{20}$ M. Zirk-Sadowski, Wystapienie Prezesa NSA na Zgromadzeniu Ogólnym Sędziów NSA w dniu 18 kwietnia 2015 r., „Zeszyty Naukowe Sądownictwa Administracyjnego” 2016, z. 3, s. 11.

21 Informacja o działalności sqdów administracyjnych w 2005 r., Warszawa 2006, s. 25-26.

${ }^{22}$ Informacja o działalności sąów administracyjnych w 2015 r., Warszawa 2016, s. 22. 
Skupiając się na procesowym aspekcie czasu trwania postępowania przed sądem administracyjnym, na jego bieg wpływ mają m.in. takie czynniki, jak ograniczony zakres uprawnień sądów administracyjnych do wydawania rozstrzygnięć merytorycznych, nadmierne gwarancje procesowe dotyczące postępowania sądowoadministracyjnego, w tym przede wszystkim postępowania kasacyjnego, wywodzone z orzecznictwa TK, oraz problematyka nadużycia prawa w tym postępowaniu.

W odniesieniu do pierwszego spośród wyróżnionych zagadnień można stwierdzić, że niewątpliwym rysem charakterystycznym modelu wymiaru sprawiedliwości sprawowanego przez sądy administracyjne w Polsce pozostają w przeważajacym zakresie kasacyjne uprawnienia orzecznicze, zarówno w I, jak i w II instancji. Podstawowym niebezpieczeństwem tego modelu jest niekończące się wędrowanie spraw pomiędzy instancjami sądowymi i administracyjnymi przez wiele lat. Niezadowolony z tego jest zarówno skarżący, który długo oczekuje na końcowe rozstrzygnięcie sprawy administracyjnej i sądowej, jak i same sądy, które po wielokroć są angażowane w rozstrzygnięcie tej samej sprawy.

Obecnie obowiązujące instrumenty procesowe przeciwdziałajace nadmiernemu przewlekaniu spraw sądowych i administracyjnych jedynie częściowo spełniają swoją rolę. Na wyróżnienie zasługuje w tym względzie obowiązek sformułowania przez sąd administracyjny w wyroku uwzględniajaccym skargę wiążących wskazań co do dalszego postępowania, które razem z oceną prawną również zamieszczoną w uzasadnieniu wyroku wiążą z mocy art. 153 p.p.s.a. organ, którego działanie, bezczynność lub przewlekłe prowadzenie postępowania było przedmiotem skargi oraz sąd przy kolejnym rozpoznaniu sprawy. W rzeczywistości jednak wskazania formułowane są zazwyczaj przez sądy zbyt ogólnie ${ }^{23}$, a organy niekiedy nawet w sposób otwarty nie stosują się do adresowanych do nich wskazań ${ }^{24}$.

W polskiej doktrynie wielokrotnie argumentowano, że sąd administracyjny, który w art. 184 Konstytucji RP powołany został do kontroli działalności administracji publicznej, nie powinien przejmować sprawy administracyjnej do końcowego rozpoznania i rozstrzygnięcia ${ }^{25}$. W przyznaniu sądom szerszych uprawnień do merytorycznego orzekania upatruje się niebezpieczeństwa naruszenia zasady trójpodziału władzy ${ }^{26}$. Warto w tym miejscu zauważyć, że

${ }^{23}$ Z tego względu w doktrynie sformułowany został postulat stworzenia wzorcowego, wielowariantowego projektu części instruktażowej uzasadnienia uwzględniającego skargę. Zob. Z. Kmieciak, Efektywność sqdowej kontroli administracji publicznej, „Państwo i Prawo” 2010, z. 11, s. 33.

${ }^{24} \mathrm{Na}$ temat ujemnych konsekwencji tego zjawiska zob. W. Piątek, Wiażace wskazania sqdu administracyjnego oraz okoliczności sformułowane w przez organ odwoławczy w perspektywie ponownego rozpatrzenia sprawy administracyjnej w: D. R. Kijowski, J. Radwanowicz-Wanczewska, M. Wincenciak (red.), Kryzys prawa administracyjnego?, t. 4: Wykładnia i stosowanie prawa administracyjnego, Warszawa 2012, s. 267-268.

${ }^{25}$ R. Hauser, Konstytucyjny model polskiego sqdownictwa administracyjnego w: J. Stelmasiak, J. Niczyporuk, S. Fundowicz (red.), Polski model sqdownictwa administracyjnego, Lublin 2003, s. 146-147; R. Hauser, A. Kabat, Wtaściwość sadów administracyjnych, „Ruch Prawniczy Ekonomiczny i Socjologiczny” 66, 2004, z. 2, s. 25-26; J. P. Tarno, w: idem et al., Sadowa kontrola administracji. Podręcznik akademicki, Warszawa 2006, s. 20.

26 B. Banaszak, J. Michalska, Artykuł 145 a ustawy-Prawo o postepowaniu przed sqdami administracyjnymi $w$ świetle Konstytucji RP, „Zeszyty Naukowe Sądownictwa Administracyjnego” 
w innych państwach europejskich, w których ta zasada również jest obecna, sądy administracyjne wyposażone zostały w szersze aniżeli w Polsce uprawnienia orzecznicze co do meritum ${ }^{27}$. Dostrzegając wobec tego polską tradycję funkcjonowania sądownictwa administracyjnego, które od czasów dwudziestolecia międzywojennego było sądownictwem kasacyjnym ${ }^{28}$, a także mając na uwadze bogaty dorobek nauki wykształcony na tle art. 184 Konstytucji RP warto podejmować refleksję nad zwiększeniem efektywności ochrony prawnej udzielanej przez sądy administracyjne. Kasacyjny model orzekania przez te sądy nie powinien zupełnie uniemożliwiać ubogacenia tych uprawnień orzeczniczych o kompetencje merytoryczne niezbędne szczególnie wówczas, gdy proces sądowy trwa kilka lat i nadal nie widać jego końca.

Drugim niebezpieczeństwem dla rozpoznania sprawy przez sąd administracyjny bez nieuzasadnionej zwłoki pozostaje nadmiernie rygorystyczne orzecznictwo Trybunału Konstytucyjnego dotyczace przede wszystkim dwuinstancyjności postępowania sądowoadministracyjnego. Uniemożliwia ono podjęcie adekwatnej reakcji do istniejacych tendencji w korzystaniu przez jednostki z ochrony sądowej. Mając na uwadze ograniczone ramy niniejszego opracowania, należy wskazać w tym miejscu tylko na jeden wyrok TK dotyczaccy konstytucyjności art. 180 p.p.s.a. w zw. z art. 178 p.p.s.a. i art. 176 p.p.s.a. W orzeczeniu tym TK rozstrzygną, że przywołana regulacja procesowa w zakresie, w jakim przewiduje odrzucenie, bez wezwania do usunięcia braków, skargi kasacyjnej niespełniającej wymogu zamieszczenia w niej wniosku o uchylenie lub zmianę orzeczenia wraz z oznaczeniem zakresu żądanego uchylenia lub zmiany jest niezgodna $\mathrm{z}$ art. 45 ust. $1 \mathrm{w}$ związku z art. 31 ust. 3 oraz z art. 78 Konstytucji, a także $\mathrm{z}$ wywodzoną $\mathrm{z}$ art. 2 Konstytucji zasadą ochrony zaufania obywateli do państwa i stanowionego przez nie prawa ${ }^{29}$.

W uzasadnieniu tego wyroku TK wyjaśnił, że odrzucenie skargi kasacyjnej sporządzonej przez adwokata bądź radcę prawnego przez sąd z powodu nieprawidłowego jej przygotowania godzi w zasadę proporcjonalności, nadmiernie ograniczając prawa do sądu i do zaskarżenia orzeczeń wydanych przez sąd administracyjny w I instancji. Trybunał wyraźnie wskazał, że odrzucenia tego nie mogą usprawiedliwiać względy szybkości postępowania. Strona skarżąca nie może z kolei ponosić negatywnych konsekwencji błędów popełnionych przez jej pełnomocnika.

Wydając wyrok w niniejszej sprawie, TK nie wzią pod uwagę tego, że zainicjowanie postępowania przed sądem wyższej instancji na ogół łączy się poszerzeniem rygorów formalnych związanych zarówno z samym wniesieniem środka zaskarżenia, jak i jego rozpoznaniem. Ograniczeniu z kolei ulega

2016, z. 4, s. 20. Odmiennie zob. Z. Kmieciak, Merytoryczne orzekanie przez sqdy administracyjne $w$ świetle konstytucyjnej zasady podziału władz, „Przegląd Legislacyjny” 2015, z. 2, s. 19-22.

${ }^{27}$ Przegląd tych uprawnień dokonany został w polskiej literaturze przez A. Skoczylasa w artykule Modele uprawnień orzeczniczych sqdów administracyjnych w Europie, „Państwo i Prawo” 2012, z. 10, s. 21 i n.

${ }^{28}$ Szerzej zob. W. Piątek, A. Skoczylas, w: R. Hauser, Z. Niewiadomski, A. Wróbel (red.), System prawa administracyjnego, t. 10: Sadowa kontrola administracji publicznej, Warszawa 2016, s. 11-28.

${ }^{29}$ Wyrok TK z 8 kwietnia 2014 r., SK 22/11, OTK-A 2014, nr 4, poz. 37. 
możliwość podnoszenia przez stronę skarżąca zarzutów, które na najwyższym poziomie instancyjnym powinny zostać zredukowane jedynie do kwestii prawnych o szczególnie doniosłym znaczeniu nie tylko w rozpoznawanej sprawie, lecz także dla rozwoju wykładni przepisów prawa ${ }^{30}$. Ten sam sposób rozumowania, wykluczający de facto możliwość jakiegokolwiek ograniczenia prawa do dwuinstancyjnego postępowania sądowego czy też zaostrzenia rygorów formalnych zaprezentowany został w innych orzeczeniach Trybunału, m.in. w wyroku dotyczacym podstaw kasacyjnych ${ }^{31}$, a w ograniczonym stopniu także w rozstrzygnięciu dotyczącym biegu terminu do wniesienia skargi kasacyjnej ${ }^{32}$.

Trzecim zagrożeniem dla sprawnego przebiegu postępowania sądowoadministracyjnego pozostaje coraz częściej obserwowane w praktyce zjawisko nadużycia prawa procesowego w postępowaniu sądowym. Polega ono na podejmowaniu przez strony prawnie dozwolonych działań dla osiagnięcia innych celów aniżeli przewidziane przez ustawę ${ }^{33}$. Prawda jest, że nie wszystkim stronom postępowania w równym stopniu zależy na szybkim jego zakończeniu. Niekiedy przed sądami występują typowi pieniacze, którzy angażują wymiar sprawiedliwości w sposób nadmierny i zarazem nieuzasadniony, ponieważ celem ich działania nie jest uzyskanie ochrony prawnej. Wydaje się, że w obecnym czasie sądy pozostają bezbronne wobec tych osób, gdyż mają obowiązek rozpoznawania formułowanych przez nich żądań z taką samą doniosłością i pieczołowitością jak w przypadku innych skarżących.

\section{SPOSOBY PRZECIWDZIALANIA NADMIERNEMU WYDLUŻANIU CZASU TRWANIA POSTĘPOWANIA SĄDOWOADMINISTRACYJNEGO}

Dążąc do przyspieszenia czasu trwania postępowania przed sądem administracyjnym, trzeba zastanowić się, w jaki sposób zarysowane powyżej mankamenty mogłyby zostać usunięte. Pomimo że trudno o wskazanie konkretnych rozwiązań, które oprócz swoich zalet byłyby pozbawione wad, warto podjaćc refleksję nad mechanizmami, które przyczyniłyby się do pełniejszej realizacji prawa do rozpoznania skargi przez sąd administracyjny bez nieuzasadnionej zwłoki.

Po pierwsze, dalszej analizy wymaga problematyka merytorycznego orzekania przez sądy administracyjne. Inspirującą w tym względzie powinna być

${ }^{30}$ Szerzej zob. W. Piątek, Glosa do wyroku TK z 8 kwietnia 2014 r., sygn. akt SK 22/11, „Zeszyty Naukowe Sądownictwa Administracyjnego" 2014, z. 4, s. 175-176.

31 Wyrok TK z 20 września 2006 r., SK 63/05, OTK-A 2006, nr 8, poz. 108.

32 Wyrok TK z 25 lipca 2013 r., SK 17/12, OTK-A 2013, nr 6, poz. 86.

${ }^{33}$ P. Przybysz, Nadużycie prawa $w$ prawie administracyjnym w: H. Izdebski, A. Stępkowski (red.), Nadużycie prawa, Warszawa 2003, s. 198; M. Hadel, Nadużycie prawa w prawie administracyjnym, „Przegląd Prawa Publicznego” 2016, z. 5, s. 51. Zob. też P. Grzegorczyk, Recenzja ksiażki M. G. Plebanka „Nadużycie praw procesowych w postepowaniu cywilnym” (Warszawa 2012), „Państwo i Prawo” 2013, z. 12, s. 114. 
obserwacja korzystania przez sądy administracyjne $\mathrm{z}$ nowych uprawnień orzeczniczych, o których stanowią art. $145 \S 3$ p.p.s.a. i art. 145a p.p.s.a.

Po drugie, analizy wymaga obecny kształt dwuinstancyjności postępowania sądowoadministracyjnego. Mając na uwadze ciąle zwiększajacy się wpływ skarg kasacyjnych wpływających do NSA, należałoby powrócić do rozważań ograniczajacych prawo do wnoszenia tego środka odwoławczego. Poza tym warto by zastanowić się także nad możliwością wprowadzenia w p.p.s.a. tzw. instancji poziomej, kiedy to środek odwoławczy przysługiwałby zamiast do NSA, powtórnie do sądu I instancji. Wydaje się, że tego typu rozwiązanie byłoby możliwe dla spraw rozpoznawanych w trybie uproszczonym.

Po trzecie, refleksji wymaga ustanowienie mechanizmów przeciwdziałających korzystaniu z procesowych uprawnień jedynie dla zasady czy też w innych celach aniżeli ochrona własnej sytuacji prawnej. Na uwagę zasługuja sformułowane już w doktrynie postulaty w tym względzie, w tym propozycja dodania do działu IV rozdziału I p.p.s.a. nowej przesłanki odrzucenia skargi kasacyjnej z powodu oczywistego braku usprawiedliwionych podstaw lub nadużycia prawa do skargi ${ }^{34}$. Poza tym warto w tym zakresie zwrócić uwage na rozwiązania, jakie w tym przedmiocie obowiąują w ustawodawstwach innych państw ${ }^{35}$.

\section{NOWELIZACJA POSTĘPOWANIA SĄDOWOADMINISTRACYJNEGO Z 9 KWIETNIA 2015 R.}

Przedstawionym niedoskonałościom przebiegu postępowania przed sądami administracyjnymi wyszła naprzeciw wspomniana we wstępie jedyna jak dotąd kompleksowa nowelizacja p.p.s.a. Oprócz wspomnianego poszerzenia uprawnień do merytorycznego orzekania przez sądy o regulację art. $145 \S 3$ p.p.s.a. oraz art. 145 a p.p.s.a. na uwage z punktu widzenia szybkości postępowania zasługują następujące zmiany.

Po pierwsze, w nowym art. $33 \S 1$ a p.p.s.a. ${ }^{36}$ zniesiony został obowiązek indywidualnego zawiadamiania przez sąd wszystkich uczestników postępowania, gdy w toku postępowania administracyjnego strony informowane były przez organ w trybie obwieszczenia lub publicznego ogłoszenia. Wprowadzona zmiana nie tylko jest ułatwieniem dla pracy sekretariatów sądowych odpowiedzialnych za realizację zarządzeń sędziowskich o wysyłce korespondencji,

${ }_{34}$ Z. Kmieciak, Nadużycie prawa do środka odwoławczego w postepowaniu sqdowoadministracyjnym, PiP 2011, z. 10, s. 31-32. Zob. też idem, Projekt regulacji prawnej dotyczqcej wstepnego badania skargi kasacyjnej w postepowaniu przed NSA, „Europejski Przegląd Sądowy” 2012, z. 2 , s. 4 .

${ }^{35}$ Zob. Przestanka potrzeby ochrony prawnej jako instrument przeciwdziałania nadużyciu prawa do skargi $w$ niemieckim postepowaniu sqdowoadministracyjnym, artykuł zaakceptowany do druku w „Zeszytach Naukowych Sądownictwa Administracyjnego”.

${ }_{36}$ Przepis ten został dodany do p.p.s.a. na podstawie art. 1 pkt 9 lit. a ustawy z 9 kwietnia 2015 r. 
lecz także prowadzi do przyspieszenia postępowania ze względu na skrócenie czasu trwania obiegu przesyłek pocztowych.

Po drugie, poszerzeniu uległ katalog spraw rozpatrywanych przez sądy w trybie uproszczonym przez dodanie do art. 119 p.p.s.a. pkt 3 i $4^{37}$. Dzięki temu na posiedzeniu niejawnym w składzie trzech sędziów zawodowych moga być rozpoznawane sprawy dotyczace skarg na postanowienia wydane w postępowaniu administracyjnym i egzekucyjnym w administracji, a także skargi na bezczynność lub przewlekłe prowadzenie postępowania.

Po trzecie, przez nowelizację art. $173 \S 1$ p.p.s.a. ${ }^{38}$ oraz art. $194 \S 1$ p.p.s.a. ${ }^{39}$ poddano modyfikacji dotychczas obowiązujaccą zasadę, zgodnie z która od wszystkich postanowień sądu I instancji kończących postępowanie w sprawie przysługiwała skarga kasacyjna. Aktualnie od postanowień o odrzuceniu skargi wydanych na podstawie art. $58 \S 1$ pkt $2-4$ p.p.s.a., art. $220 \S 3$ p.p.s.a. oraz postanowień o umorzeniu postępowania przysługuje zażalenie. Jak zostało to wyjaśnione w uzasadnieniu projektu ustawy nowelizującej, zaskarżalność postanowień zasadzajacych się na stosunkowo łatwo identyfikowalnych okolicznościach faktycznych i prawnych za pomoca wysoce sformalizowanej skargi kasacyjnej nie była celowa ${ }^{40}$.

Po czwarte, do p.p.s.a. dodany został nowy art. 179a ${ }^{41}$, dzięki któremu wprowadzona została względna dewolutywność skargi kasacyjnej. W ten sposób NSA odciążony został od rozpatrywania skarg kasacyjnych, które ze względu na oczywistą zasadność podstaw kasacyjnych bądź też zachodzącą w sprawie nieważność postępowania powinny zostać uwzględnione już na etapie postępowania przed sądem I instancji ${ }^{42}$.

Po piąte, znowelizowane zostało brzmienie art. 188 p.p.s.a. ${ }^{43}$, dzięki czemu istotnie poszerzono możliwość wydania orzeczenia reformatoryjnego przez NSA. Sąd ten, uwzględniając skargę kasacyjna, obowiązany jest rozpoznać także wniesioną do wojewódzkiego sądu administracyjnego skargę, jeżeli uzna, że istota sprawy została dostatecznie wyjaśniona ${ }^{44}$. NSA orzeka w ten sposób jednocześnie w obu instancjach, a wydane orzeczenie kończy postępowanie sądowoadministracyjne.

Każda z zasygnalizowanych jedynie zmian powoduje, że postępowanie przed sądem administracyjnym toczy się sprawniej. Trzeba w tym miejscu zauważyć,

\footnotetext{
${ }^{37}$ Powyższa zmiana nastapiła na podstawie art. 1 pkt 27 ustawy z 9 kwietnia 2015 r.

38 Zob. art. 1 pkt 48 ustawy z 9 kwietnia 2015 r.

39 Zob. art. 1 pkt 57 ustawy z 9 kwietnia 2015 r.

${ }^{40}$ Zob. uzasadnienie projektu ustawy z 9 kwietnia 2015 r. http://www.sejm.gov.pl/Sejm7.nsf/ druk.xsp?nr=1633 [dostęp: 29.11.2016].

41 Zob. art. 1 pkt 52 ustawy z 9 kwietnia 2015 r.

42 Szerzej zob. W. Piątek, A. Skoczylas, M. Wiącek, Względna dewolutywność skargi kasacyjnej w postęowaniu sadowoadministracyjnym, „Zeszyty Naukowe Sądownictwa Administracyjnego" 2016 , z. 3 , s. 37 i n.

43 Zob. art. 1 pkt 55 ustawy z 9 kwietnia 2015 r.

${ }^{44}$ Wskazana przesłanka jest jedyna, która warunkuje wydanie orzeczenia na podstawie art. 188 p.p.s.a. Przepis ten nie zawiera jakiejkolwiek negatywnej podstawy podjęcia wskazanego rozstrzygnięcia. Szerzej zob. R. Hauser, W. Piątek, A. Skoczylas, Środki odwoławcze w postepowaniu sqdowoadministracyjnym w świetle ustawy nowelizujacej z dnia 9 kwietnia 2015 r. - analiza najistotniejszych zmian, „Zeszyty Naukowe Sądownictwa Administracyjnego” 2015, z. 4, s. 18.
} 
że dokonanie wymienionych modyfikacji było $\mathrm{w}$ dużej mierze wynikiem analizy praktyki orzeczniczej sądów administracyjnych ${ }^{45}$. Mówiąc inaczej, na przykładzie ustawy z 9 kwietnia 2015 r. widać, w jak istotnym stopniu uważna lektura orzecznictwa sądowego może stanowić asumpt do zmian obowiązującego prawa.

\section{PODSUMOWANIE}

Przedstawione powyżej uwagi z całą pewnością nie wyczerpują wszystkich problemów i wątpliwości pojawiających się w odniesieniu do czasu trwania postępowania sądowoadministracyjnego. Powinny one stanowić punkt odniesienia dalszej dyskusji na temat sprawności oraz szybkości tego postępowania. Nawet bowiem umiarkowanie pozytywna ocena obecnego czasu trwania procedury sądowoadministracyjnej nie powinna zwalniać od refleksji na temat wprowadzenia rozwiązań proceduralnych, które obecny stan rzeczy mogłyby zmienić na lepsze.

Z przeprowadzonych rozważań płynie wniosek, że nie istnieje jeden prosty mechanizm proceduralny, którego zastosowanie umożliwiłoby znaczace przyspieszenie czasu trwania postępowania sądowoadministracyjnego. Szans $\mathrm{w}$ tym względzie warto upatrywać $\mathrm{w}$ zwiększeniu uprawnień do merytorycznego orzekania przez sądy, co już miało miejsce mocą postanowień ustawy z 9 kwietnia 2015 r., modyfikacji istniejącego modelu dwuinstancyjności postępowania sądowoadministracyjnego oraz przeciwdziałaniu przypadkom nadużycia prawa procesowego.

Mając na uwadze zwiększajacy się stopniowo wpływ skarg i skarg kasacyjnych, nie należy odkładać zbytnio w czasie podejmowania prób zaradzenia niebezpieczeństwu nadmiernego przeciążenia sądów administracyjnych, a szczególnie NSA w rozpoznawaniu skarg kasacyjnych. Wprowadzone z tą myśla zmiany moca ustawy z 9 kwietnia 2015 r. zasługują na aprobatę. Nie powinny one wszakże prowadzić do zakończenia rozważań nad dalszym usprawnieniem biegu postępowania przed sądami administracyjnymi.

Nawiązując do wskazanych we wstępie niniejszego opracowania wyrażonych przed wejściem w życie p.p.s.a. poglądów na temat czasu trwania postępowania sądowoadministracyjnego w nowym, dwuinstancyjnym jego modelu, trzeba zauważyć, że nie potwierdziły się ani nazbyt optymistyczne, ani też pesymistyczne wizje jego przebiegu. Szczególnie w odniesieniu do wojewódzkich sądów administracyjnych uzasadnione jest przyjęcie tezy, że działają one sprawnie. Aktualnie wysiłki powinny zostać skupione na zapewnieniu zbliżonego poziomu szybkości działania NSA.

dr hab. Wojciech Piatek

Uniwersytet im. Adama Mickiewicza w Poznaniu

wojciech.piatek@amu.edu.pl

45 Uwaga tego rodzaju została wprost wyrażona w uzasadnieniu projektu ustawy z 9 kwietnia 2015 r., http://www.sejm.gov.pl/Sejm7.nsf/druk.xsp?nr=1633 [dostęp: 29.11.2016]. 


\section{EXAMINATION OF THE MATTER BY THE ADMINISTRATIVE COURT WITHOUT UNDUE DELAY}

\section{Sum mary}

One of the elements of the right to a court is the exercise of this right within a reasonable time. The aim of the study is the analysis of this condition in the judicial activity of Polish administrative courts. This activity has been analysed both from the point of view of available statistics which show a gradually increasing influence of complaints and cassation appeals and the regulations of the Law on Proceedings before Administrative Courts. A moderately positive assessment of the efficiency of administrative litigation has been formulated. It has been found that although proceedings before regional administrative courts are conducted relatively quickly, efforts should now be focused on ensuring a similar level of turn-over in proceeding before the Supreme Administrative Court. 
